\title{
Nuevos lugares y viejos recuerdos: Continuidades latentes y diversidad cultural entre los inmigrantes peruanos de Madrid $^{1}$
}

\author{
MARÍA ASUNCIÓN MERINO \\ Dpto. de Historia de América \\ Instituto de Historia. CSIC. Madrid
}

\section{RESUMEN}

A través del análisis de los criterios que organizan la sociabilidad de los inmigrantes limeños en Madrid, devotos del Señor de los Milagros, este artículo indaga sobre el proceso de reterritorialización cultural entre ellos. Expone las continuidades latentes que aparecen en las categorías de identificación y diferenciación puestas en juego en sus relaciones sociales, y la relevancia de los contextos locales de origen y de llegada en la diversidad de modos en que estos inmigrantes experimentan su pertenencia nacional.

Palabras claves: Inmigración, Peruanos, Reterritorialización cultural, Identidad nacional, Continuidades latentes.

\section{SUMMARY}

This paper inquires into the process of cultural reterritorialization among immigrants through the analysis of the criteria used by those coming from Lima, devotees of El Señor de los Milagros (the Lord of Miracles), to organize their sociability in Madrid. The article reveals the latent continuities in their categories of identification and differentiation, brought into play in their social relations, as well as the relevance of both origin and destiny in the different ways these immigrants experience their national sense of belonging.

Key words: Immigration, Peruvians, Cultural reterritorialization, National identity, Latent continuities.

\footnotetext{
${ }^{1}$ Las ideas aquí expuestas fueron debatidas en el X Encuentro de Latinoamericanistas (Salamanca, mayo del 2004) y en el II Congreso Internacional de Peruanistas en el Extranjero (Sevilla, junio del 2004). Aunque el contenido de este trabajo es de mi exclusiva responsabilidad, quisiera agradecer la atenta lectura y las sugerencias de Juan J. R. Villarías Robles y de Cristina Sánchez-Carretero, del Departamento de Antropología de España y América del Instituto de la Lengua Española, CSIC, y de Ángel Díaz de Rada Brun, del Departamento de Antropología Social y Cultural de la Facultad de Filosofía, UNED.
}

RDTP, LIX, 2 (2004): 221-255 
It may be too premature to announce the end of nationalism or to romanticize transnationalism in an increasingly global world. Nationalist ideas and practices continue to circulate worldwide and organize much of people's everyday lives (Duany 2000).

Being no longer an essence, national identity becomes a given subject position at a given strategic moment which corresponds to a relation of Self to the Other. That may be why a "Peruvian" deterritorialized discourse and sentiment arises so easily among migrant workers having left this country, affluent enough to be more Peruvian than ever, but poor enough not to afford embracing global cosmopolitanism (Protzel 1999).

\section{MULTIDIMENSIONALIDAD DE LAS IDENTIFICACIONES}

[...] significa que tengas fe en el Señor de los Milagros, porque como católico que eres tienes que creer en alguien [...]. Pero en resumidas cuentas todos llegamos a un mismo punto y como el Señor de los Milagros es el Patrón de Perú, pues hemos querido sacar al Patrón de Perú [...]. En cuanto les nombras al Señor de los Milagros, la gente viene de cualquier sitio porque tiene más arraigo, más influencia (Capataz de la Hermandad del Señor de los Milagros (HSM) de San Romualdo, entrevista, noviembre 1997).

Yo toda mi vida he sido católica, ¿no? O sea, mi santo ha sido el Señor de los Milagros (Jefa del Grupo de Damas de HSM San Romualdo, entrevista, julio 2003). Hay una identificación con el Señor de los Milagros [...]. Es una devoción limeña [...]. En otros lugares veneran al Señor de Luren, que es también un Cristo (Hermana de la HSM de María Inmaculada, entrevista, julio 2003).

En la pasada década de los noventa, inmigrantes peruanos crearon en Madrid tres hermandades en honor de la imagen más venerada de su país, la del Señor de los Milagros. De las tres asociaciones me han interesado especialmente la de San Romualdo (en la parroquia del mismo nombre, en el distrito de Ciudad Lineal) y la Agrupación de Devotos de María Inmaculada (en la parroquia de ese nombre en el distrito Centro), que son las más populares entre los peruanos. La organización se orienta al momento de la procesión, cuando, por lo general, los hombres cargan la imagen (en grupos de cargadores o cuadrillas) y las mujeres inciensan y cantan durante el recorrido (componiendo los grupos de damas). Todas las Hermandades del Señor de los Milagros (en adelante, HSM), dentro y fuera de Perú, copian la imagen de la HSM de las Nazarenas de Lima, 
ubicada allí en la Iglesia llamada así; pues es la hermandad que conserva la pintura original y, por ello, la principal HSM. En Madrid, en las de San Romualdo y María Inmaculada encontramos que algunos de los devotos consideran peruana la imagen, otros además limeña y todos ellos coinciden en señalar que es católica. Muchos piensan que el Señor de los Milagros es el Patrón de Perú y otros, el de Lima. Para unos cuantos, mantener la devoción al Señor de los Milagros en España es mantener su fe católica; para otros significa continuar sus costumbres como peruanos:

Yo creo que uno no debe perder su costumbre. En este caso, [la costumbre] del Señor de los Milagros. Nosotros los peruanos no perdemos nuestras costumbres (Hermano de HSM de San Romualdo, entrevista, julio 2003).

La mayoría de los devotos participa en la procesión un día del mes de octubre y en otras actividades de las hermandades un par de veces al año. Algunos, además, acuden a la misa que se celebra en la parroquia un domingo de cada mes. Los menos asisten a las reuniones de las cuadrillas y a las asambleas de la hermandad. En cada uno de estos encuentros, los participantes acompañan a la imagen en procesión, aportan fondos, asisten a los eventos festivos y deportivos que organiza la hermandad, oyen misa o pasan un rato en la parroquia.

En estas actividades, los hermanos se identifican entre sí como inmigrantes, peruanos, católicos y devotos del Señor de los Milagros; pero ni componen un grupo homogéneo ni se perciben como tal, sino que activan otras dimensiones de su identificación. Hombres y mujeres traban conversación por separado en las reuniones, como constaté. Las mujeres con niños a menudo limitan su participación a los eventos festivos. Los solteros y casados alternan por su cuenta fuera de la hermandad. En estos momentos de reencuentro con compatriotas que hacía tiempo no veían o con los habituales, hablan con conocidos, amistades y amigos de un modo escogido y, después, cada quién va con su grupo a un bar a "tomar" (beber), a un restaurante (peruano) o a casa de alguno a comer y pasar la tarde:

Vamos con mucha frecuencia, cada vez que hay asambleas, reuniones, actividades; pues nos llaman [...]. Dentro de la hermandad tenemos un pequeño grupo (hermanos de María Inmaculada, entrevista, julio 2003).

Los últimos domingos de cada mes hay misa y después hay un ágape para los que van y ahí se reúne la gente; estás conversando y eso. [Después] a veces vamos a casa de alguien o a comer a un restaurante, según... (hermanos de San Romualdo, entrevista, julio 2003)

Dentro de la hermandad hay subgrupos; no todos son necesariamente amigos. Se conocen y se relacionan pero cada uno clasifica a los demás 
como "amigos", "amistades" o "conocidos" según sus propios términos. Otras formas de identificación se activan, además de las de "católicos", "peruanos" o "devotos del Señor de los Milagros": los "hombres" y las "mujeres"; los "solteros" y los "casados"; "serranos" y "urbanos"; "cholos" y "limeños de toda la vida"; "pitucos" (del distrito de Miraflores en Lima), de "clase media" (Jesús María), de barrios "populares" (Lima) y de "Pueblos Jóvenes" (San Martín de Porres); "los que tienen educación" o "los que tienen cultura" y los que no tienen ni una cosa ni la otra; los "que quieren mejorar" y los "que siguen igual".

Desde una lógica externa (desde el otro lado de la frontera) este estudio no tendría más sentido; cabría pensar que los peruanos van con peruanos y además todos ellos son inmigrantes, comparten nacionalidad, realidad (migratoria) y encima devoción a una misma imagen. En la bibliografía sobre la inmigración en España, sus autores y, en general, la sociedad receptora, suelen clasificarlos por su origen nacional, su condición inmigrante e, implícitamente, por su bajo status social, dado el tipo de empleos en que se ocupan. Lo que da lugar a este artículo sobre la sociabilidad de los devotos del Señor de los Milagros comienza en ese punto.

En otro trabajo analicé el uso de las categorías "inmigrante" y "peruano" frente a las de "católico" y "devoto del Señor de los Milagros" (Merino 2002a); en éste trataré de desvelar otras categorías de identificación que organizan la sociabilidad de estos "inmigrantes peruanos". En la línea de las reflexiones de Gupta y Ferguson (1997) surgen preguntas tales como ¿Qué criterios siguen para recrear su lugar en un nuevo espacio? ¿En qué consiste el proceso de reterritorialización cultural de los sujetos migrantes? ¿Qué lugar ocupa la categoría nacional en la reproducción de los contextos de "localidad", en el sentido que Appadurai (1996: 182) otorga a este término?

Es posible, como Malkki (1997) plantea, que el análisis de los procesos migratorios desde una perspectiva "sedentaria" que prioriza la dimensión nacional desde una ideología nacionalista, derive en interpretaciones poco acertadas de la realidad cotidiana de los sujetos; pero el estudio de la transformación de las identidades de los migrantes en clave de "cosmopolitismo" o "diáspora", llevado al extremo, corre el riesgo de convertirse más en una propuesta políticamente correcta que en un diagnóstico certero de lo que está ocurriendo, como ha advertido Friedman (1997: 75).

La migración nutre la experiencia de la alteridad así como vuelve más complejo el proceso de construcción de la identidad. A su vez, lleva a considerar la actuación sinérgica de los contextos, tanto de llegada como de partida. A la hora de analizar la construcción de un nuevo lugar por 
parte de los inmigrantes, hay que tener presente no sólo las prácticas de categorización del Estado receptor sobre ellos sino también la memoria de éstos. En el proceso dinámico de construcción de la identidad, el sentido de pertenencia nacional, junto al local y al universal, se convierte en una continuidad latente al tiempo que se actualiza y expresa de modos diversos, aconteciendo una gama amplia de situaciones intermedias entre la exaltación y su disolución, según los contextos sociales de referencia, que han de ser estudiadas.

Con respecto al contexto de partida, la sociedad peruana contiene numerosas diferencias culturales según las regiones. Fruto de estas diferencias y de la migración a la capital desde los años cuarenta, Lima - lugar de origen de muchos inmigrantes peruanos en Madrid- se ha vuelto más diversa que nunca en las últimas décadas y, en consecuencia, en ella se observan numerosas divisiones y fragmentaciones sociales y culturales que, a su vez, generan entre los limeños una diversificación cultural, social y local. En cuanto al contexto de llegada, éste no se refiere sólo a la visión de los recién llegados por parte del Estado como "inmigrantes" - una categoría excluyente marcada por la frontera estatal y la clasificación sociolaboral - sino también a la experiencia migratoria que confronta al inmigrante con un "otro" que contribuye a redefinir su proceso de construcción de identidad.

Desde este punto de partida, el presente trabajo indaga sobre el proceso de reconstrucción del sentido de pertenencia en los inmigrantes limeños en Madrid: cómo se activan sus múltiples niveles, en qué consiste analíticamente su diversidad interna, cómo se reconstruye un lugar en un nuevo espacio a partir de la memoria de otro lugar y cuáles de las categorías de identificación que entran en juego son continuidades latentes. En este proceso de reterritorialización local me interesa también la vivencia de lo nacional.

Como contexto de análisis, he tomado el caso de las hermandades del Señor de los Milagros en Madrid como uno de los espacios sociales más visibles que los peruanos han construido en la ciudad. A través de entrevistas y de la observación, he tratado de reconstruir la sociabilidad de los hermanos: cómo se estructura, cuáles son sus componentes, cuáles los criterios y contenidos. Si el arraigo suele emplearse a menudo en un sentido nacional (y "los peruanos se arraigan más a las personas", como me explicaba el capataz de la segunda cuadrilla de la HSM de San Romualdo), cabe descubrir con quién van y por qué.

A partir del análisis de las relaciones sociales de tres profesionales peruanos (una pareja y un joven soltero) que emigraron a Madrid en momentos distintos y proceden de zonas diferentes de Lima Metropolita- 
na, pretendo mostrar con este artículo la relevancia de los contextos locales, tanto de partida como de llegada, en la producción de localidad de los sujetos migratorios. Entre otras coordenadas que organizan su sociabilidad en el nuevo espacio, las múltiples estratificaciones y diferenciaciones, sociales y culturales, que estos inmigrantes marcaban entre sí en Perú se reproducen ahora y configuran distintas maneras de ser "peruano" en el ámbito local. La delimitación del estudio a los casos de limeños se debe a su presencia mayoritaria entre los oriundos de Perú en Madrid y a las posibilidades que ofrece un lugar de origen como Lima Metropolitana para el estudio de las cuestiones referidas, por su enorme diversidad cultural y las grandes transformaciones que vienen aconteciendo desde la segunda mitad del siglo veinte.

Luis, Helio y Elena son "limeños", que tratan de "auto-blanquearse" ante los connacionales con los que se relacionan en Madrid, a través de diferenciadores locales, sociales y culturales, construidos en el lugar del que proceden: su nivel de instrucción, su origen social y étnico o su posición económica. Su disímil procedencia de barrio y cultural en Lima, así como el diferente contexto social al que se incorporan en Madrid, también condicionan el que no otorguen el mismo significado a su devoción por el Señor de los Milagros o a sus relaciones sociales en Madrid, ni sean categorizados de igual manera entre otros "peruanos", así como tampoco perciban su "peruanidad" del mismo modo.

Empezaré por presentar las transformaciones de Lima Metropolitana durante las últimas décadas, que explican la enorme complejidad y diversidad de la sociedad limeña. A continuación expondré los diferentes orígenes socioeconómicos, culturales y de barrio de los limeños en Madrid, lo que constata la diversidad de los contextos de partida de estos "inmigrantes"; si frente a los españoles son "peruanos", entre ellos se califican de diferentes maneras, según otros criterios. Lo social, lo cultural y lo económico se mezclan de modo que es imposible separarlos en el nivel local.

\section{LA DIVERSIDAD DE LOS INMIGRANTES PERUANOS EN MADRID}

\section{La transformación de Lima Metropolitana}

Para comprender la profundidad y complejidad de la diversidad social y cultural del contexto de partida, hay que considerar la gran transformación de la sociedad peruana, en especial la limeña, acaecida durante las últimas cinco décadas. El país ha sido protagonista de un cambio notable: se ha triplicado y urbanizado en gran medida la población nacional 
(el $50 \%$ se concentra hoy en las mayores ciudades del país), se han incrementado los niveles de alfabetización, fruto de mejoras en el ámbito escolar, y ha aumentado la exposición a los medios de comunicación ${ }^{2}$ (Golte 1995: 135-6).

Con estas innovaciones, "las grandes diferencias de estilos de vida y de expectativas posibles en las diversas regiones del país se volvían insostenibles. No es de extrañar entonces, que la población peruana se haya vuelto altamente móvil" (Golte 1995: 137). Durante los años cuarenta y cincuenta se aceleró la migración a las ciudades y se constituyeron las bases de la urbanización de Perú. Desde entonces la llegada de provincianos a Lima ha sido continua, representando en 1981 el 45,4\% del total de la población limeña (Driant 1991: 83). Por sobrepoblación, necesidad y deseo de mejores oportunidades económicas, la gente oriunda de provincias fue abandonando el campo hacia una ciudad, Lima, que no estaba preparada para tal magnitud de llegadas (Driant 1991).

Desde 1940, los migrantes fueron llegando a la capital, en muchos casos procedentes de comunidades indígenas sobre las que tradicionalmente había recaído el estigma del atraso y la ignorancia (Protzel 2001: 151; Matos 1988: 89; Fuenzalida 1970: 17). Con la migración, estos andinos sufrieron un proceso de "cholificación" por el que abandonaron elementos de su cultura indígena mientras adoptaban otros propios de la "occidental criolla" (Quijano 1980: 87 y 63), algo que algunos ya habían comenzado a hacer en sus lugares de origen ${ }^{3}$. Estos "cholos" pasaron a formar parte de la "población obrera o de las capas bajas de la clase media" de Lima (Quijano 1980: 67).

Con el tiempo, estos serranos han dejado atrás su pasado aldeano y se han vuelto urbanos (Golte 1995: 45) pero, lejos de sufrir un proceso de "desculturación generalizado" (Degregori 1986: 51), se han modernizado a su manera (Franco 1991). Han cambiado el "mito de Incarrí" por el "mito del progreso" y han conquistado el espacio limeño a través de la escuela y el trabajo de tal modo que hoy pueden "reconocerse como pe-

\footnotetext{
${ }^{2}$ En 1993, el $73 \%$ de los hogares en Perú tenía televisión y un porcentaje mayor, radio (Golte 1995: 136).

3 El "cholo" o "indio ex-campesino" (Mayer 1970: 120) al principio era "el indígena desarraigado de su sociedad por el trabajo migratorio estacional" (Fuenzalida 1970: 77); un joven bilingüe que no se empleaba en tareas agrícolas ni ocupaba una posición servil, presentaba una elevada movilidad social y compartía elementos, tanto de la cultura indígena como de la occidental criolla (Quijano 1980: 64-65). Según quien lo emplee y en qué contexto, el término "cholo" tiene múltiples significados, peyorativos en muchos casos. En Lima se refiere a los migrantes provincianos con la connotación negativa de una persona "arribista", que aspira a un nivel social que no le corresponde por origen (Fuenzalida 1970: 79-80) y que puebla las "barriadas marginales" (Quijano 1980: 87).
} 
ruanos, trabajadores y ciudadanos" (Degregori 1986: 54). Los migrantes han "desbordado" Lima con su incorporación particular, tanto al sistema productivo, en su impulso de la economía informal, como a la sociedad, con el mantenimiento de dinámicas sociales y culturales propias de sus comunidades de origen (Golte y Adams 1987; Matos 1988). Si Lima era antes una sociedad criolla y homogénea, cuando los andinos se mantenían en las zonas rurales, ahora se ha vuelto "mestiza" (Protzel 2001).

La capital ha sido "invadida" por estos migrantes (Degregori, Blondet y Lynch 1986), quienes han convertido tanto los distritos históricos del centro en barrios populares como los terrenos periféricos en "pueblos jóvenes" ${ }^{4}$ (Matos 1988) donde hoy en día se concentra el 35\% de la población (Riofrío 2003). Como consecuencia, la sociedad limeña ha ido apartándose del modelo de jerarquización étnica que la caracterizaba para dar paso a uno de mercado (Golte 1995: 146), tal que hoy en día existen "mayores posibilidades de movilidad social" (Golte 1995: 146) aunque continúan las diferencias - más bien fronteras- culturales y sociales, en gran parte vinculadas a los barrios de residencia.

Fruto de esta migración masiva que ha recibido la capital, los vecinos de los distritos medios ahora consideran "peligrosos" a los barrios del centro —donde antes vivían- (Portocarrero, Valentín e Irigoyen 1991: 57) y a las barriadas, sinónimo de pobreza y delincuencia (Riofrío 2003), así como a sus habitantes: gente "pobre", de "clase bajísima", "sin cultura" y "de barrios peligrosos" (adjetivos de dos limeñas de barrios medios). Para las clases medias, "de una identidad más criolla que andina, y más blancos o mestizos que cholos o indios, [que] han solido representar el logro y la decencia, la modernidad, ante los sectores populares, [...] se multiplican los espacios hostiles" (Portocarrero et al. 1991: 58).

En cambio, los de las barriadas prefieren llamar "asentamiento" a su lugar de residencia, aunque eludan mencionar que viven alli; como es el caso de los jóvenes que buscan empleo en el centro para evitar ser discriminados (Riofrío 2003: 7). Con respecto a lo que opinan de la clase media, para ellos "buena parte [...] resulta extranjera" (Portocarrero et al. 1991: 42). En comparación con ella, y desde el sentimiento de rechazo

\footnotetext{
${ }^{4}$ Los términos "barriada" y "pueblo joven" se usan desde los años cincuenta para designar asentamientos de personas de bajos ingresos en las zonas periféricas de la capital, donde la gente primero se asienta, después construye sus casas y luego instala los servicios. Así los denomina la prensa y la clase media limeña aunque su denominación oficial es "asentamiento humano" o "popular" (Riofrío 2003: 5-6). Con respecto a otros barrios, en ellos se registra un menor nivel educativo y ocupacional, peor dotación de servicios públicos y mayores concentraciones de pobreza extrema, pero no integran un grupo homogéneo: existen diferentes grados de desarrollo y condición socioeconómica entre ellos (Riofrío 2003: 11).
} 
por su parte, los sectores populares se sienten diferentes. Esta sensación se acentúa al constatar que sus gustos y costumbres están influidos, tanto por la cultura criolla como por la andina (Portocarrero 1993a: 21). Se caracterizan por su laboriosidad, "la alta valoración del trabajo y la disponibilidad para el esfuerzo", así como por su confianza en la Providencia, en lo maravilloso (Portocarrero 1993a: 16-17): dos actitudes de raíces andinas que se mezclan con valores del capitalismo, como la creencia en el progreso. Otra de sus características es la relevancia que otorgan a los vínculos de parentesco y, en menor medida, a los de paisanaje y vecindad, basados en una relación de reciprocidad implícita (Portocarrero 1993a: 22).

La Lima de la que llegan los inmigrantes a Madrid parece haberse vuelto una ciudad compartimentada (Stein 2003) o más bien, se podría pensar, un lugar donde las fronteras internas se han multiplicado, como si algunas pudieran ser atravesadas y hubieran de darse todas a la vez para encontrar un compartimento infranqueable. De este modo, la "práctica discriminatoria" del "cholear" resulta una combinación "compleja" de elementos con que los limeños "se evalúan entre sí", tales como los rasgos físicos, el nivel socioeconómico, el escolar (incluido el dominio del español) y la "calidad de migrante" (Twanama 1992: 222). Por ejemplo, si "la pobreza y el lugar de origen cholean", el título universitario y el dinero "blanquean" (Twanama 1992: 221). Las valoraciones negativas son atribuidas a características sociales referidas, tanto al lugar de procedencia, como a la etnia, la posición social, el aspecto físico o la valoración intelectual (Cosamalón 1993: 280) ${ }^{5}$.

En proceso continuo, la identidad peruana se ha ido transformando durante las décadas pasadas de tal modo, que "en el cruce de caminos entre identidades étnicas, clasistas, regionales, y al menos, embrionariamente ciudadanas" (Degregori 1995: 316) surge no ya una manera de ser peruano, como señala este autor, sino múltiples. En el proceso migratorio, esta transformación de la identidad (identidades) nacional - explicada por Degregori en términos estatales - se adecúa (y acelera), como apunta Protzel (1999).

A pesar de la transformación urbana de estas últimas décadas, el país no ha logrado desarrollarse económicamente al mismo nivel. "Ha habido una acumulación en infraestructura y en 'capital humano' pero no lo su-

5 De un estudio del término "cholo" entre los jóvenes limeños, se observa su uso para "marginar y despreciar", significa "lo bajo e inferior" y representa una frontera social. De forma espontánea, los entrevistados adjudicaban valores negativos como "feo", "inferior", "bruto", "animal", "huachafo" (vulgar o de mal gusto), a identificaciones étnicas y características sociales: "serrano, indio, mestizo, moreno, criollo, pobre, ambulante, campesino, música andina, chicha” (Cosamalón 1993: 281). 
ficiente como para hacer crecer los ingresos per capita y no de la calidad necesaria como para evitar que caigan sostenidamente desde 1975" (Gonzáles de Olarte 1995: 41). En la segunda mitad de los años setenta, la economía pasó del crecimiento a la contracción. En la década siguiente, las sucesivas políticas de estabilización y ajuste estructural de los gobiernos de Belaúnde y Alan García dieron lugar, entre otras consecuencias, a una disminución de los ingresos per capita y a un incremento de la pobreza y la desigualdad; en los años finales, el país se hallaba en medio de una crisis económica y política (Verdera 1997; Thomas 1999; Álvarez 1995) que se acentuó con los enfrentamientos entre el ejército y el grupo terrorista Sendero Luminoso. A comienzos de los noventa esta tendencia se mantendría con la política de estabilización del presidente Fujimori (Figueroa 1995).

No es de extrañar, pues, que la población peruana otra vez se haya vuelto móvil desde los años ochenta y que el nuevo destino se haya ubicado fuera de las fronteras estatales. Estados Unidos ha sido el principal país receptor, al que le siguen México y Venezuela, entre otros. Cuando, a principios de los noventa (Altamirano 1992), la política migratoria de EE.UU. se volvió más restrictiva (Portes y Rumbaut 1990), otros países latinoamericanos y europeos empezaron a cobrar relevancia como receptores de inmigrantes peruanos. Desde los ochenta España se ha convertido en un país de inmigración, no exigiendo visado de entrada a los nacionales de Perú hasta 1993. Aquí, los peruanos se han incorporado a la construcción y, en mayor medida, a los servicios (Ministerio de Asuntos Sociales 2002: 276). Estos sectores se han beneficiado de la llegada de inmigrantes en su búsqueda de mayor flexibilización de las condiciones laborales (Colectivo Ioé 1990,1998) para reducir costes y adaptarse más rápidamente a las demandas del mercado (Sassen 2000; Stepick y Grenier 1994).

En Madrid, la gran mayoría de los peruanos emigrados en los noventa se emplea (y subemplea) en trabajos no cualificados: servicio doméstico (limpieza y cuidado de personas) - la mayor parte-, restauración (ayudantes de cocina o camareros), construcción (ayudantes de albañilería, fontaneros, pintores, etc.), comercio y empresas de mensajería (Merino 1999: 184-200). Sólo una minoría, que llegó a España probablemente durante los años ochenta y a principios de los noventa, ha logrado empleos cualificados: un $8 \%$ como profesionales (enfermeras, médicos, ingenieros, abogados); un $3 \%$, administrativos; un $2 \%$, técnicos; y otro $3 \%$, pequeños empresarios (ver Cuadro 1$)^{6}$.

\footnotetext{
${ }^{6}$ La base de datos del consulado peruano en Madrid es la única fuente que aporta la información presentada y analizada en este artículo, a lo largo del texto y en
} 
CUADRO 1

Clasificación de las ocupaciones de los peruanos en Madrid

\begin{tabular}{|l|c|}
\hline \multicolumn{1}{|c|}{ Clasificación ocupacional } & Porcentaje \\
\hline Empresarios & 3 \\
Profesionales & 8 \\
Técnicos & 2 \\
Administrativos & 3 \\
Servicios & 9 \\
Agricultura & 0 \\
Industria & 4 \\
Maquinaria & 3 \\
Trabajador no cualificado & 55 \\
Empleados & 13 \\
\hline TOTAL & 100 \\
\hline
\end{tabular}

FUENTE: explotación estadística de la base consular

\section{Los inmigrantes peruanos en Madrid}

La inmigración peruana en España comenzó destacar en la segunda mitad de la década de los ochenta para incrementarse notablemente durante la siguiente; si sumamos el número de inscritos en el consulado durante esas dos décadas, el $82 \%$ habría llegado en los noventa. El volumen de este flujo migratorio convirtió a los peruanos en el colectivo latinoamericano más numeroso en España, el segundo en el conjunto total de inmigrantes, por detrás de los marroquíes y por delante de los domi-

los cuadros: la ocupación de los peruanos en España y en Perú así como el domicilio de residencia en Lima. Los datos disponibles caracterizan a los peruanos que entraron durante las décadas de los ochenta y noventa. Después, la política del consulado cambió, no permitiendo acceder directamente a la base y aportando únicamente tablas incompletas, inexactas y poco detalladas que en absoluto completan la explotación estadística ya realizada, si es que no la dificulta; conseguir una tabla fiable exige un enorme labor previa de limpieza de datos, algo que las autoridades consulares no están dispuestas a realizar. Por todo ello resulta inviable la actualización de estos datos. Hay que señalar, por otra parte, que la jurisdicción del consulado peruano en Madrid comprende además Castilla La Mancha, Castilla-León y Extremadura; sin embargo, para el $94 \%$ de los casos registrados, su lugar de residencia es la Comunidad de Madrid y las entrevistas detectaron en su momento el progresivo desplazamiento desde las provincias hacia la capital, así que consideraremos los resultados de la explotación estadística de la base como referidos a la Comunidad de Madrid. 
nicanos (Ministerio de Trabajo y Asuntos Sociales 1999: 300). En el nuevo milenio, la presencia de los peruanos ha quedado diluida por su progresiva adopción de la nacionalidad española, el menor número de ingresos y ante la llegada masiva de ecuatorianos y colombianos.

Como revela la base de datos del consulado peruano, la mayor parte de los peruanos residentes Madrid que emigraron en los ochenta y noventa, son urbanos y limeños; el $77 \%$ son de Lima Metropolitana $(90 \%$ de Lima, $10 \%$ del Callao) $)^{7}$, aunque el $23 \%$ no ha nacido alli ${ }^{8}$. Su procedencia limeña es muy diversa; si la mitad $(49,3 \%)$ viene del Centro ${ }^{9}$, esta proporción se reparte en múltiples distritos: Lima ${ }^{10}$, Rímac (18\%), Miraflores (17\%), Breña (8\%), Jesús María (7\%), La Victoria (7\%), Pueblo Libre, Lince y San Isidro ( $6 \%$ cada uno). De los otros Conos, la población originaria se concentra en unos pocos. Del Norte son el 20\%: Comas (32\%), San Martín de Porres (27\%) y Los Olivos (18\%); del Este, el 16\%: San Juan de Lurigancho (54\%) y Ate (23\%); del Sur, el 14\%: Surco (40\%), Chorrillos (25\%) y Villa M. ${ }^{a}$ del Triunfo (12\%).

\footnotetext{
${ }^{7}$ Lima Metropolitana comprende los distritos de las provincias: Lima y Callao, del Departamento de Lima. Explotación estadística del campo "domicilio en el Perú" de la base consular (Merino 1999: 469).

${ }^{8}$ Aún así, entre limeños y no limeños, el $74 \%$ ha nacido en capitales de provincias. Lima capital, 48,5\%; Callao, 5,5\%; Trujillo, 6\%; Arequipa, 3\%; Chiclayo, 2\%; Huancayo, 2\%; Piura, $1.2 \%$, entre otras.

${ }^{9}$ Los distritos que componen Lima Metropolitana se distribuyen en cuatro conos o zonas: Centro, Norte, Sur y Este. El Centro comprende: Lima, Barranco, Breña, Jesús María, La Victoria, Lince, Magdalena del Mar, Magdalena Vieja, Miraflores, Rímac, San Borja, San Isidro, San Miguel y Surquillo. El Norte: Ancón, Carabayllo, Comas, Independencia, Los Olivos, Puente Piedra, San Martín de Porres y Santa Rosa. El Sur: Chorrillos, Lurín, Pachacamac, San Juan de Miraflores, Santiago de Surco, Villa El Salvador, Villa María del Triunfo, Santa María del Mar, San Bartolo, Punta Negra, Punta Hermosa y Pucusana. El Este: Ate, El Agustino, La Molina, Lurigancho, San Juan de Lurigancho, San Luis, Santa Anita, Chaclacayo y Cieneguilla.

${ }^{10}$ El porcentaje de población que procede de Lima es difícil de cuantificar con exactitud; aunque más de la mitad de los casos contenían esta respuesta, se desconoce si son de la provincia o del distrito. Lo mismo sucede con El Callao; donde además el número de casos por distritos es poco representativo.
} 
CUADRO 2

Clasificación social de los distritos de origen de Lima Metropolitana*

\begin{tabular}{|l|c|}
\hline \multicolumn{1}{|c|}{ Tipología de los distritos de procedencia } & Distribución \\
\hline RESIDENCIAL: S. Isidro, S. Luis, Monterrico & $5 \%$ \\
MEDIO: Miraflores, Surco, Jesús María, Pueblo Libre, Lince, San & $31 \%$ \\
Borja* & $8 \%$ \\
MIXTO: Breña, Magdalena del Mar, Barranco & $33 \%$ \\
POPULAR: Lima, S. Juan de Lurigancho, Rímac, S. Martín de & \\
Porres, La Victoria, Surquillo & \\
BARRIADA: Comas, Chorrillos, Los Olivos*, Villa M. a Triunfo, In- & \\
dependencia, Villa El Salvador, Carabayllo, San Juan de Mi- & $21 \%$ \\
raflores & $2 \%$ \\
\hline SIN ESPECIFICAR: Santa Anita, Pucusana, Santa Rosa & 100 \\
\hline TOTAL &
\end{tabular}

* Se ha considerado San Borja y Los Olivos según la clasificación de Ponce (1995) por percentiles de pobreza: San Borja, más parecido a Miraflores (medio) y Los Olivos, a Comas (barriada). Fuente: Elaboración propia a partir de Driant (1991) y Ponce (1995) ${ }^{11}$

Es significativa esta heterogeneidad en los distritos de procedencia, si consideramos no sólo la desigualdad que refleja su clasificación socioeconómica $^{12}$ (ver Cuadro 2), sino también la diversidad cultural implícita, así como el hecho de que para la sociedad limeña estas diferencias son elementos a considerar en sus prácticas discriminatorias: "blanquean" o "cholean", según quién proceda de dónde. Los distritos más representati-

${ }^{11}$ Driant (1991: 75-81) califica socialmente a los distritos según esta clasificación: RESIDENCIAL: 0-5\% tugurio (vivienda en mal estado o superpoblada), 0-5\% barriada: distritos de la gran burguesía limeña. MEDIO: 7-14\% tugurio, 0-5\% barriada: distritos de la clase media. MIXTO: 14-24\% tugurio, 0-5\% barriada, mezcla, alto porcentaje de tugurios. POPULAR: (CENTRAL) $14-24 \%$ tugurio, $10-30 \%$ barriada; $30-50 \%$ viviendas populares, aunque probablemente el porcentaje sea mayor. (PERIFERICO): 0-5\% tugurio, $30-50 \%$ barriada; $33-40 \%$ vivienda popular. BARRIADA: (CENTRAL) 7-14\% tugurio, $30-50 \%$ barriada, $49-59 \%$ vivienda popular, marcado por barriadas pero en tejido urbano (BARRIADA): $0-5 \%$ tugurio, $50-100 \%$ barriada.

${ }^{12}$ Esta clasificación no excluye considerar que ahora parece haber "mayor diferenciación al interior de cada distrito" (Ponce 1995: 138), concentrándose en cada uno gente de sectores "pobres", "populares"y "medios", según el Instituto Apoyo (Ministerio de Energía y Minas 2004: 11-13). En los años ochenta esta clasificación era más clara, ya que los barrios eran más homogéneos; pero en cualquier casọ, en Miraflores reside más población de grado medio (profesionales, con alto nivel educativo y necesidades básicas satisfechas) que en Lima y aquí más que en Comas o San Juan de Lurigancho, donde la mitad de sus vecinos es clasificada como "pobre" (Ministerio de Energía y Minas 2004: 11-13). Cuando hablamos de pobreza hay que considerar que en Lima se distinguen ya tres niveles (Encuesta de Apoyo del 2001 en Ministerio de Energía y Minas, 2004: 12) y que en 1991 el $49 \%$ de su población se hallaba en estado de pobreza crítica y otro 10\%, extrema (Encuesta de CUANTO en Ponce 1995: 140). 
vos son tanto populares como medios y barriadas: Lima y Rímac (entre los populares céntricos), San Juan de Lurigancho y San Martín de Porres (populares con un alto porcentaje de barriadas), Miraflores y Surco (entre los medios) y Comas y Los Olivos (entre las barriadas). El 33\% de los limeños procede de distritos populares, el $31 \%$ de los medios y el $21 \%$ de las barriadas (ver Cuadro 2); aunque es probable que este porcentaje último sea mayor que el que las fuentes aportan ${ }^{13}$.

Estos datos revelan que en Madrid se han asentado limeños procedentes, tanto de sectores populares como medios; los hay de origen andino, los hay mestizos y los hay criollos. Esta diversidad local aquí presente es el marco necesario para que algunas de las estratificaciones y diferenciaciones sociales y culturales que los limeños establecen en Lima, como las generadas por la etnia y el lugar de residencia, puedan ser reproducidas en Madrid. Para la sociedad limeña, no es lo mismo haber crecido en San Isidro que en Breña o en Comas, por las connotaciones atribuidas a estos distritos. Tampoco es lo mismo ser un profesional o un empleado de la Administración que un vendedor ambulante, una empleada doméstica o un conductor de combi. En cuanto a sus ocupaciones, las fuentes también muestran que los inmigrantes peruanos no componen un colectivo homogéneo.

Cuadro 3

Clasificación laboral/ocupacional de los peruanos antes de emigrar a Madrid

\begin{tabular}{|l|c|c|}
\hline Situación laboral/Ocupaciones & 1980-89 (\%) & 1990-97 (\%) \\
\hline Inactivos (estudiantes 75\%) & 47 & 35 \\
Empresarios (comerciantes 80\%) & 3 & 7 \\
Profesionales (medios y superiores) & 20 & 17 \\
Técnicos & 3 & 4 \\
Administrativos & 4 & 7 \\
Servicios & 1 & 1 \\
Agricultura / Pesca & 0 & 0 \\
Industria & 1 & 3 \\
Maquinaria & 0 & 1 \\
Trabajadores no cualificados & 1 & 1 \\
Empleados & 20 & 24 \\
\hline TOTAL & 100 & 100 \\
\hline
\end{tabular}

FUENTE: Explotación estadística de la base de datos del consulado peruano en Madrid

${ }^{13}$ Por dos razones, primera, porque la valoración peyorativa de una procedencia de barriada pueda haber disuadido a sus residentes de mencionarlo en el consulado $\mathrm{y}$, segundo, porque los distritos del Callao no han sido incluidos, una zona donde se concentra una proporción elevada de sectores populares y pobres (Encuesta de Apoyo del 2001 en Ministerio de Energía y Minas 2004: 13). 
Durante los años ochenta, los peruanos que llegaban a Madrid eran, en su mayoría, jóvenes que venían a realizar estudios universitarios ( $47 \%$, profesionales de grado medio y superior $(20 \%)$ y empleados $(20 \%)$. En la década siguiente, la composición laboral y ocupacional cambió, disminuyendo relativamente la proporción de estudiantes y profesionales mientras aumentaba el porcentaje de empleados ${ }^{14}$, comerciantes y administrativos (ver Cuadro 3).

Esta pluralidad ocupacional permite vislumbrar diferencias, entre los limeños en Madrid, respecto de su nivel escolar y su posición social en Lima: otros elementos que se combinan en la práctica del "cholear" y que pueden ser activados en las relaciones que establezcan los limeños entre sí en Madrid.

\section{CONTINUIDADES LATENTES Y RETERRITORIALIZACIÓN CULTURAL}

Una vez que hemos atravesado la frontera nacional y nos colocamos al otro lado, en la conversión de una parte de Madrid en un nuevo Perú, descubrimos que los miembros de las hermandades, al relacionarse entre sí, marcan otras fronteras internas, porosas y flexibles, que corresponden a clasificaciones latentes creadas en su lugar de origen y activadas aquí según con quién se relacionen y en qué contextos; diferencias en las que se cruzan la adscripción barrial o regional, el origen social y étnico, la ocupación, el estado civil y el género. En los casos de limeños aquí analizados, los valores y formas de identificación y diferencia que ponen en juego en la reconstrucción de un lugar en otro espacio varían según sus lugares de procedencia, en Lima, y el contexto social en el que se insertan, en Madrid.

${ }^{14}$ A la hora de explotar estadísticamente la base del consulado peruano en Madrid, de donde proceden estos cálculos, surge la dificultad de interpretar el término "empleado". Economistas españoles y peruanos aconsejaron su exclusión -como categoría aparte- de la clasificación que se realizó siguiendo la Clasificación Nacional de Ocupaciones de 1994 de España. Tentativamente se puede afirmar, por los datos de otros campos y las entrevistas, que una proporción de los empleados de los ochenta y primeros años de los noventa pudieran proceder del sector formal del mercado, mientras que para los datos de la segunda mitad de los noventa (tras la privatización de las empresas públicas y ante la grave situación de la economía peruana) proliferaran los del sector informal (Merino 1999). Si en la base aparecen detallados miles de tipos de trabajos, sobre todo los de manufactura, curiosamente no se mencionan los de servicios personales como vigilante, empleada doméstica o conductor de combi o taxi. 
Luis: la vivencia de la barriada y el mestizaje

Como la mayoría de los peruanos en Madrid, Luis es limeño de nacimiento. Sus padres son de Cañete, una provincia costera del Departamento de Lima, eminentemente rural, desde donde emigraron a la capital en busca de mejores oportunidades, asentándose en San Juan de Lurigancho. Este distrito se formó en los años cincuenta con la migración y, a fines de los ochenta, concentraba un cuarenta por ciento de "viviendas populares", la mayor parte de las cuales son barriadas (Driant 1991: 80). En los noventa ocupa el puesto más alto en el ranking de pobreza por distritos limeños (INEI 1994 en Romero 2003) y concentra el mayor porcentaje de hablantes de quechua (13\%) (INEI 1993c: Cuadro 9). Se trata de uno de los distritos más densamente poblados (Romero 2003), del que procede un volumen notable de emigrantes limeños.

En Lima, Luis consiguió completar su formación universitaria superior, obteniendo una licenciatura en Administración de Empresas, algo poco común entre los residentes de San Juan de Lurigancho ${ }^{15}$. Su contexto familiar debió de ser difícil; su padre, contable de profesión, gastaba más dinero en beber que en sostener a la familia y él se puso a trabajar desde muy joven. Recuerda su adolescencia como una etapa marcada por su afición a "tomar" con sus amigos del barrio y a buscar bronca. Ahora sólo bebe ocasionalmente, no sólo porque sea consciente del gasto y el drama familiar que eso supone, sino también por la nueva vida de laboriosidad y religiosidad que inició en Lima, tras varias visiones de la Virgen en sueños, premoniciones y algún que otro milagro que le sucedió.

A pesar de que su novia ya había emigrado a Madrid, se empeñó en obtener su título académico antes de reunirse con ella. Mientras, trabajaba y ahorraba para pagarse el billete. Su novia era una amiga de su hermano, de su barrio, que había estudiado en el mismo colegio. Se habían hecho novios en 1997, en una ocasión en la que ella volvía a Lima para visitar a su familia y, desde entonces, fue a verlo todos los años a Lima hasta que él emigró en 2001 a Madrid. Luis llegó con la intención de casarse, pero un año después terminaría su noviazgo por desavenencias

${ }^{15}$ En 1993, el $8 \%$ de la población ocupada de San Juan de Lurigancho había alcanzado una formación universitaria superior mientras el $70 \%$ había obtenido, como mucho, el grado de educación secundaria. En comparación, el $21 \%$ de los vecinos de Breña tenía estudios superiores completos, el $58 \%$ había alcanzado la educación secundaria y el resto, alguna formación técnica o universitaria (INEI 1993a y 1993b: Cuadro 46 de San Juan de Lurigancho y de Breña). 
con su familia política. Aunque ella estaba dispuesta a pagarle el pasaje de vuelta, Luis no quiso regresar a Perú.

De sus amigos de Lima, Juan está también en España. Se trata de un compañero de la universidad y vecino del barrio que se asentó hace años en Madrid con su esposa, sus hermanos y sus padres, y recientemente ha montado un negocio de mensajería. La familia de Juan ya conocía a Luis, lo aprecia y este grupo de personas es su referente social en Madrid. Sin embargo, Luis no puede "alternar" con ellos porque es soltero y ellos están casados. En el lugar del que procede, un hombre de treinta años debería estar casado o al menos tener novia; su soltería corre el riesgo de ser interpretada como señal de homosexualidad.

[Juan] me dijo: "yo te conozco de la graduación, sal adelante"[...]. Su hermana, todos: "si ella no estaba en tu futuro, olvídate". Su madre me decía: "hombre, yo te conozco desde chico [...] saldrás adelante". Y Su padre: "vamos, no te des por vencido, tú eres un hombre, hay muchas mujeres aquí".

Tras la ruptura con su novia, Juan le animó, le consiguió empleo en la construcción, donde antes trabajaba, y le puso en contacto con peruanos que hoy son sus amigos. Uno de ellos, Pedro, le dio alojamiento en su casa, lo llevó a trabajar en la construcción con él y lo integró en la hermandad de San Romualdo como hermano de la primera cuadrilla. Allí lo presentó a los demás como su sobrino, porque para ellos existe cierta familiaridad entre ambos: Pedro es amigo de un tío de Luis y su esposa Clara lo es de la madre. Los tres son del mismo barrio, casi de la misma cuadra. El matrimonio lo ha apadrinado brindándole su protección y él, en señal de respeto, los llama "tíos", estableciendo con ellos una relación basada en la reciprocidad. Reconoce la generosidad de la que ha sido objeto, todo son palabras de agradecimiento por su apoyo y, en cuanto pueda, les devolverá el favor, una actitud que a él le parece de "buen peruano":

El cariño y el respeto [que me han dado], me han apoyado..., y por eso olvidarme [de Pedro y Clara] es difícil para mí, porque yo siempre he valorado a las personas que te ayudan sin pedir nada a cambio. Somos así: cuando alguien nos brinda un apoyo nunca nos olvidamos [...]. Eso es costumbre de los peruanos, de los españoles no lo sé.

Mientras intenta homologar su título universitario y lamenta la falta de una novia, se concentra en otras necesidades más prioritarias: ganar dinero, tener un lugar donde dormir, regularizar su situación y traer a su hermano, con sus ahorros y un precontrato de trabajo. Ha realizado multitud de "chapuzas" en la construcción, se ha empleado como camarero y hace unos meses ha conseguido ser contratado en una tienda de alimen- 
tos como repartidor. Durante un año ha recurrido a los comedores públicos de Madrid - ha perdido quince kilos-, algo que para muchos peruanos forma parte de un pasado oscuro como emigrantes recién llegados: representa el fracaso temporal de sus expectativas y un retroceso en el objetivo de movilidad social, algo que es mejor olvidar.

La hermandad de San Romualdo, de la que Luis forma parte, es una de las más prestigiosas de Madrid. Fue creada en 1994 por profesionales y empresarios, limeños de buena posición social que habían llegado en los ochenta y establecido vínculos con la embajada y el consulado peruanos (Merino 2002b: 121). Poco antes de que llegara Luis, a principios de la década de 2000 , una parte de este grupo se había escindido para formar una nueva HSM en otra parroquia ${ }^{16}$. A pesar de ello, la HSM de San Romualdo sigue siendo la más reconocida de las que hay en Madrid y en ella hay limeños, tanto de barrios medios como populares y de barriada.

Por su situación tan precaria al comienzo, los demás hermanos consideraron a Luis un "cualquiera", un "vago", según sus palabras; lo "ninguneaban" y le negaban que fuese trabajador, una de las pocas virtudes que honra a la gente de barriada como él. Lo han "choleado" porque ellos tienen mejores trabajos, estabilidad laboral y legal, una mayor capacidad de consumo y están en pareja, mientras él es un migrante recién llegado,

\footnotetext{
${ }^{16}$ El grupo que se escindió quería conservar el control de la entidad mediante su presencia perpetua en los órganos de poder, el Directorio y las Comisiones, lo que originó un profundo conflicto con algunos socios nuevos, de clases medias y populares, que querían ocuparlos. Para el caso de las HSM en Estados Unidos, Paerregaard (2004: 11) interpreta este tipo de divisiones internas (que a veces terminan en escisiones) como producto de las diferencias de clase: entre los inmigrantes peruanos de elevado estatus que arribaron hace décadas y los que llegaron hace poco procedentes de las barriadas y zonas rurales. En su consideración, los primeros conocerían lo relativo al culto de la imagen y su objetivo primordial sería éste, mientras que los otros buscarían hacer nuevos contactos más que la devoción en sí. En las HSM en Madrid se constata igualmente que las diferencias de clase han jugado un importante papel en la escisión. En este caso, habría que matizar que el conflicto emergió por el control de los cargos y era más enconado entre miembros de la misma clase social, incluso antiguos amigos. Es decir, que en un principio se trataba de la lucha por los cargos directivos; no es extraño encontrar disputas por este motivo en las hermandades, ya que una de las funciones que cumplen para sus miembros es la búsqueda de prestigio y realización personal dentro de la comunidad (Celestino y Meyers 1981). Por otro lado, la creación de la hermandad beneficiaría indirectamente a sus fundadores con publicidad, por su participación generosa, y con la captación de nuevos clientes entre los inmigrantes que llegaban; algunos tenían negocios de envío de dinero. El problema no era que los nuevos inmigrantes, procedentes de barriadas y pueblos, ingresaran en la hermandad, algo que fomentaban los fundadores, sino que quisieran ocupar los órganos de poder.
} 
como los que arribaban a Lima décadas atrás. No ha conseguido un buen empleo y está lejos de alcanzar cierto progreso material; hasta hace poco compartía habitación con cinco ecuatorianos; además, todavía no se ha casado, ni siquiera tiene novia. Todavía está con un permiso temporal y le llevará tiempo y esfuerzos obtener uno definitivo o la nacionalidad; a los ojos de los demás hermanos, está en una posición inferior; su capital económico es menor aunque con el tiempo aquéllos han descubierto su capital académico (Bourdieu 1998); con el tiempo han sabido que estudió una carrera, que es un profesional, y por eso lo miran con más respeto ahora; su status ha mejorado:

Hay mucha gente que se cree la gran cosa [en la hermandad], porque está en España, porque tiene quince años o porque tiene la nacionalidad. Porque trabaja en el Corte Inglés o en el consulado o en la embajada, se creen la gran cosa.

En la hermandad se relaciona con los amigos de Pedro, limeños de barriada también que ahora ocupan los cargos directivos. Entre ellos, su condición civil - soltero a pesar de su edad- y su etapa inicial como emigrante no le permiten conseguir el reconocimiento que espera; pero al mismo tiempo, el ser hombre, de barriada y tener formación universitaria, le han permitido recibir el respeto y la ayuda del grupo de hermanos que frecuenta. En cambio, otros limeños, también de barriada, lo han "choleado" aunque no tengan formación como él y Luis les critica no sólo que lo discriminen sino también que se olviden de sus orígenes:

Porque te voy a decir la verdad: yo soy de barrio y allá en Perú, cuando son de barrio y ganan un poco de dinero y viajan a algún país, ya se creen la gran cosa. Yo no soy así. No era el típico que pasa en mi país, que el que gana un poquito ya no quiere a sus amigos de barriada [...]. Especialmente en la hermandad hay gente que se quiere dar de matones, de grandes empresarios. No, mira, como dicen en Perú, un buen pendejo no muestra sus habilidades; te mira, te observa antes de atacar. Eso es lo que yo hago.

No se queja, en cambio, de los limeños de clase media. Éstos son un mundo aparte, se siente diferente a ellos. Luis es astuto, "pendejo" ${ }^{17}$, mientras que ellos son "pitucos ${ }^{18 ", ~ " n i n ̃ a t o s " ~}{ }^{19}$ como los españoles y, en parte, le resultan extranjeros (Portocarrero et al. 1991: 42). Como él expli-

\footnotetext{
${ }^{17} \mathrm{La}$ acepción peruana del término "pendejo" significa persona astuta y taimada (RAE 2003)

${ }^{18}$ En Perú, "pituco" se refiere a una persona de clase alta (RAE 2003): el equivalente a "pijo" en España.

${ }^{19}$ En su sentido despectivo, un "niñato" es alguien petulante, presuntuoso (RAE 2003).
} 
ca: "Allá la gente de barriada es más astuta que el "pituco" [...] por sobrevivir, si comparas con los niñatos [españoles] que viven con sus padres".

En el fondo está orgulloso de su lucha constante por encontrar empleo y superar su soledad, la separación de su familia, la ruptura con su novia y las adversidades en el trabajo; incluso ha conseguido no caer en la tentación de participar en negocios ilegales. Su progresiva resolución de problemas se lo debe a sus amigos, a su arranque personal y a la providencia divina. Su creencia en lo divino es clave en su propia interpretación de lo que está viviendo. Cuando habla, su referencia a lo religioso es constante: Cristo es quien le ayuda en sus logros (que son milagros), quien le pone obstáculos (que son su cruz), quien se le aparece en sueños. A él reza: lee salmos cada día, que le dan fuerza para superar una realidad tan adversa. Ante tantos apuros, su devoción al Señor de los Milagros se va acrecentando. Su progreso — su destino- está vinculado a Dios $^{20}$, pero también a su propia laboriosidad:

Antes era devoto de la Virgen de las Mercedes. Ese tiempo yo no creía [en Dios] pero [...] entraba a verla [a la iglesia] y soñaba con ella [...]. Hablaba con un sacerdote y no me creía. Soñaba que iba en avión antes de conocer a mi ex pareja. No se qué me pasa, veía un avión [...] y un día mi ex me dijo: "quiero que te vengas a España". [Otra vez] me ocurrió un milagro. Un amigo me dijo: "acércate que te van a dar la tarjeta". Me la dieron [...] Y otro [me dijo]: "iestás trabajando? Acércate ahí"[...]. Ese mes se me presentó la habitación, la tarjeta de residente y el trabajo. Se lo debo a Dios.

Con Pedro y con los hermanos que él le ha presentado, a veces sale a "tomar" después de las reuniones. El alcohol es el eje de sociabilidad de este grupo que frecuenta; para ellos beber es de machos. Aunque él apenas "toma" y es muy consciente de los problemas que se derivan del alcoholismo, comprende que la gente lo haga como una costumbre peruana y una forma de compartir, divertirse, celebrar, así como una expresión de estima hacia el otro:

Yo ya no tomo. En la hermandad siempre las típicas bromas: "que eres un maricón, porque no tomas...". En la hermandad [hay mucha] gente divorciada por muchos factores, entre otros el alcohol. Es que el peruano no pierde la costumbre, una es la comida [...] otra es la borrachera que se da. Lo digo como peruano: Yo lo respeto, a X, tal vez tenga el defecto de tomar, pero no soy nadie para juzgar... Mi padre tomaba [...] tenía más para gastar en beber que en su familia [...] Navidad [...] allá hacen un fiestón y comparten todo, un picnic [...], una borrachera que se dan, no por la fiesta sino por la estima que se dan, porque nació Jesús..., por divertirnos.

${ }^{20}$ Una actitud religiosa semejante se refleja en la devoción a Sarita en Lima; se trataría de una "confianza mágica", como la denomina Portocarrero (1993b: 180-181). 
Para Luis, compartir la bebida, la comida peruana, los recuerdos de Lima y la devoción al Señor de los Milagros, mantener las costumbres peruanas y hacer amigos, o contactos para conseguir empleo o cualquier otra cosa que se necesite: todo ello explica las reuniones de los devotos de la hermandad, dentro y fuera de ella.

[La hermandad] está hecha de ese amor hacia Dios, de la devoción al Señor de los Milagros [...] y a la vez, entre ellos, está la borrachera, de ir a un restaurante peruano a comer su ceviche, a una fiesta; está unido con el amor de Dios. Va unido todo. Después de las reuniones [alguien dice]: "bueno, vamos a recordar la época de juventud, vamos a comernos un ceviche peruano o tirarnos unas cañas". [Por] no perder la costumbre del típico peruano de comer su ceviche, el plato favorito en Perú, y de sus cervezas y sus fiestas, su música criolla, todas esas cosas maravillosas de cada país.

Según Luis, el mantenimiento de las costumbres es algo propio del buen peruano, como él se considera; es algo que defiende contra la asimilación forzada, en su opinión, de otros compatriotas. En ningún momento habla de ser limeño, más se identifica con ser de barrio. Una de sus aficiones es escuchar música y califica de peruano, tanto un vals criollo limeño como un huaino de la sierra - aunque su familia no sea serrana-, fruto del mestizaje de la Lima posterior a la migración interna, que emerge de los sectores populares y que es impulsada por ellos (Degregori 1986: 54).

El peruano no pierde su costumbre [...] y no perdemos nuestra tradición [...]. Los típicos peruanos no perdemos nuestras costumbres [...]. El error de nosotros los inmigrantes es que algunos [...] queremos imitar a la gente española. Creo que uno no debe perder su costumbre [...] del Señor de los Milagros [...]. La comida, sólo he comido tres veces comida española. Me cocino mi propia comida, que es peruana.

Luis frecuenta los bares y restaurantes peruanos que hay cerca de su casa. Además de ser una forma de "mantener sus costumbres", para él son una fuente importante de contactos, un referente clave, donde ampliar su sociabilidad al margen de la hermandad; encuentra vecinos de su barrio con los que hace nuevas amistades y consigue información y contactos que le facilitan su vida de emigrante. Así se ha hecho amigo de Pablo, peruano, que le ha ayudado mucho.

Gracias a que ellos [los peruanos] ponen sus negocios hace que nos unamos más, porque acá no perdemos la costumbre típica de la comida. Vamos a un restaurante peruano porque nos encontramos con compatriotas que nunca nos hemos visto. Me salgo a encontrar con gente del barrio o primos, primas, o medio hermanos que nunca se han visto allá y que han venido a encontrarse acá. 
Durante su segundo año conoció en los, comedores públicos a otros compatriotas que estaban en su misma situación de recién llegados; como Hugo, que le presentó a su esposa Carlota y a sus hermanos. Son de Chimbote, costeños como los padres de Luis. Con ellos comparte los mismos problemas, se ayudan mutuamente, se hacen compañía, pasaron juntos la Navidad y los visita cada semana. Lo tratan como a uno más de la familia; medio en broma le hablan de la hermana de Carlota, que aún está en Perú, como su futura novia. Aunque esta familiaridad no es recíproca: para Luis su familia son sus "tíos" Pedro y Clara. Sin embargo, con Hugo, Carlota y su familia mantiene una dinámica diferente a la que lleva con los hombres de la hermandad o con Pablo: no sale a los bares, sigue el buen camino del ahorro y la religiosidad.

Con los españoles apenas se relaciona. Sus experiencias con ellos no han sido muy positivas. Ha discutido con varios por sus actitudes racistas, ha recibido golpes de alguno y soportado las habladurías de sus compañeros de trabajo. Pocos son los conocidos amables; entre ellos, una señora mayor ya jubilada que vive sola y a la que Luis visita a veces, le hace compañía y ella lo aconseja y anima. También su actual jefe, que le ha hecho contrato de trabajo, lo está ayudando en la tramitación de los permisos y le hará un precontrato de trabajo a su hermano para que pueda venir. Asimismo, algunas jóvenes españolas de otras provincias, con las que ha contactado virtualmente, a través de los "chats" de Internet: conversan de sus problemas y se dan consejos, pero nunca las ha conocido personalmente.

Helio y Elena: el acriollado de barrio céntrico y el clasismo

Helio y Elena proceden de Lima Metropolitana. Una parte de la familia de Helio es de Ica, pero él ha nacido y vivido en Breña, un barrio céntrico, "mixto" con tugurios (Driant 1991: 79), de "clase media empobrecida", como lo calificarían los limeños de barrios medios. La familia de Elena es de Piura, una provincia costera donde ella nació y vivió su infancia y adolescencia. De allí partió con su hermano hacia Lima para estudiar en la universidad. Con el tiempo pasaron a residir en el distrito de Lima, clasificado como "popular" por la abundancia de tugurios y algunas barriadas (Driant 1991: 79). Breña, como la misma Lima, creció demográficamente con la migración desde los años cincuenta (Driant 1991: $82,85)$.

Elena y Helio cursaron estudios universitarios. Él obtuvo la licenciatura de Tecnología Médica, especialidad de laboratorio, en la Universidad 
Nacional Federico Villarreal, y ella, el grado medio de "técnico laboratorista". Se conocieron cuando trabajaban en un hospital público en Lima. Allí se casaron y tuvieron su primer hijo. Gracias al capital de sus padres, a su formación y a su profesión, ambos habían logrado alcanzar allí cierto status social; como ellos dicen: "para nosotros era bonito, una carrera que haces porque te gusta [...]; trabajábamos de lunes a viernes y el fin de semana libre, para hacer otras cosas, pasear".

Pero la crisis económica y el terrorismo en Lima truncaron sus expectativas sociales. Cuentan que fue el terrorismo lo que les hizo salir del país, pero omiten referir que su capacidad de consumo era cada vez más reducida con su salario público. España, adonde ya había emigrado una hermana de Helio, representaba la posibilidad de poder dedicarse a su profesión, ganar un buen salario -algo que no tenían en Lima- y disfrutar de sus ratos de ocio:

Había mucho rapto a médicos y enfermeros para atender a terroristas [...]. Nos amenazaron, dos veces. Nos mandaron cartas. Sabían que yo [Helio] trabajaba en el hospital y les podía sacar medicamentos más baratos y, si no..., ya sabían dónde vivía. Si no, no hubiéramos venido. Hay mucha gente que ha venido por necesidad, por su situación económica [...]. Nuestros padres tuvieron una situación más o menos buena, podíamos decir, y no teníamos necesidad de emigrar.

Su ideal es trabajar en lo que les gusta, tener tanto estabilidad laboral como un buen sueldo que les permita "darse gustos" y poder disfrutar de sus momentos de ocio. En su opinión, "todo el mundo aspira a tener un nivel de vida holgadillo, que te permita vivir, [y] esto no es vivir". Es duro no encontrar un empleo como "laboratoristas" y, en cambio, tener que dedicarse al cuidado de ancianos, por lo que trae consigo una ocupación como ésta: inseguridad laboral, un salario bajo, verse forzados al pluriempleo y a trabajar los fines de semana y apenas tener tiempo libre.

Después de ocho años como emigrantes, aún no han conseguido trabajar en laboratorios españoles a pesar de sus múltiples esfuerzos enviando currículos y tramitando la convalidación. Sólo Elena ha logrado que su carrera técnica sea homologada, pero de poco le ha servido. Incluso hizo un curso de auxiliar de enfermería ofrecido por la Comunidad de Madrid y, como ella dice, "de las prácticas no pasas".

Me inscribí en muchas partes, estuve como tres años pagando la cuota por socio [en la Asociación profesional] y no me han ofrecido ningún trabajo. He enviado currículo a clínicas, hospitales y nada. He pedido prácticas para reciclarme y nada... $y$ te ves que no, te van pasando los años y te cuesta ejercerlo...

Sus dificultades laborales y legales les recuerdan que no nacieron en España. A lo largo de estos años han experimentado situaciones frustran- 
tes, como no conseguir un empleo adecuado a sus estudios ("no te sientes plenamente realizado acá"), buscarlo de cualquier cosa, tratar de conseguir cada año que les hagan contrato y que les renueven el permiso de trabajo (los primeros son anuales) así como el constante papeleo en las oficinas de la Administración española. Estas adversidades les han llevado, entre otros motivos, a solicitar la nacionalidad española:

Una de las primeras razones que nos llevó a hacer el cambio de nacionalidad fue eso, principalmente, estar hasta aquí de tener que decirle a fulanita de tal que tenía que estar haciéndote un contrato de trabajo, explicarle que era una puerta. "No, es que no te hago un contrato, que no sé que..." Le tenías que pedir su declaración de la renta, nómina..., pasarte todos los meses aunque no trabajases, pagar la Seguridad Social (porque si no, no te renovaban [el permiso]), hacer colas, perder tres, cuatro semanas. Y dijimos: la nacionalidad.

Ante tantos obstáculos para desempeñar su profesión, con el dinero ahorrado ahora intentan montar un negocio de exportación de materiales de laboratorio a Perú, algo muy relacionado con sus estudios. Paralelamente, él piensa estudiar Medicina en Madrid, previa convalidación de su carrera de laboratorista con cursos de la de Medicina en Lima. Además, han conseguido un piso subvencionado por la Comunidad de Madrid y les gustaría comprarse un coche.

Su condición de empleados del sector servicios en el mercado secundario los iguala al resto en cuanto a posición social en Madrid. En este sentido, sin embargo, su percepción es que están más preparados para su trabajo, ya que pueden aplicar sus conocimientos, por ejemplo, en las cuestiones referidas al cuidado de enfermos y su "educación" les permite tener un trato más refinado con españoles; además, luchan por mejorar su situación laboral.

En la hermandad de Santa María Inmaculada se relacionan frecuentemente con un grupo "educado" de amigos, profesionales, con el que se identifican más. Su status social en Lima, así como su afán por recuperarlo, les hace percibirse como "gente de clase media" frente al resto de los hermanos que no tienen su formación universitaria, ni tenían su posición social allí:

Dentro de la hermandad tenemos un pequeño grupo, aparte, sí... que solemos vernos frecuentemente, que nos identificamos más, por amistad y eso... Justamente coincidimos, nos comportamos ecuánimemente... Por lo menos tienen... un nivel, unos estudios, un comportamiento.

En estas y otras afirmaciones, como las que siguen sobre otros miembros de la hermandad, se activan diferenciaciones propias de la sociedad limeña. En su pequeña comunidad de devotos reproducen ciertas clasifi- 
caciones en las que no sólo ponen en juego el nivel educativo, sino también, en cierta manera, el origen barrial y el status social en Lima, así como la diferencia étnica. Ellos no se consideran migrantes serranos de barriada, ni andinos, sino criollos de barrio céntrico:

Hay gente que no tiene nada. Han venido de provincias, del campo. No tienen ni el más mínimo conocimiento del buen estar. Pero, bueno, tampoco es apartarlos por eso... Se expresan de una manera que... Pues no empleamos esas palabras. Allá las emplean gente que... no tiene cultura, decimos allá.... Y cuando están en trago, ya pierden el comportamiento... y ya ahí no nos gusta... Nos apartamos... $\mathrm{Y}$ hay mucho, mucho de eso, muchos peruanos; pero cuando estás entre peruanos que están estudiando y eso, no pasa eso.

Curiosamente, es Elena la que afirma esto, que es de "provincia", y además se refiere a los del "campo", cuando el $89 \%$ de los inscritos en el consulado procede de los enclaves urbanos más desarrollados del país (Lima Metropolitana, Arequipa y Trujillo) y el $96 \%$ de capitales de Departamento $^{21}$. Como me explicó una informante limeña, en esa referencia a la gente "de provincias", Elena diferencia entre los provincianos como ella, que fueron a estudiar a una universidad en Lima porque sus padres podían pagarle los estudios, y los que vinieron "del campo" y "sin cultura", los campesinos serranos que fueron a vivir a las barriadas y "no tienen educación, toman y no respetan".

Sus afinidades locales concretan la diferencia regional y barrial, social y étnica. Helio y Elena se identifican como criollos limeños, educados y de cierto status. Él es limeño de clase media baja y ella, de clase media de provincias. Sus amigos son como ellos, limeños, de barrios céntricos de Lima, mixtos y populares (Breña, Lima o Surquillo), formados en alguna profesión y con aspiraciones: no son de Miraflores ni Surco, pero tampoco de San Martín de Porres.

En la hermandad componen el grupo "con educación", de un origen social medio y de barrio céntrico, frente a los que apenas completaron la educación secundaria y proceden de barriada, algo a tener en cuenta en su valoración social, además de sus logros como emigrantes en Madrid. Aunque su residencia en barrio popular y su pasado familiar provinciano no pasaría desapercibido para un "limeño de toda la vida" de clase media, este grupo no forma parte de su hermandad. Todos los hermanos participan en el juego de las apariencias y cada uno presume de lo que le da valor a los ojos de los demás y oculta lo que le hace inferior.

\footnotetext{
${ }^{21} \mathrm{La}$ explotación estadística de la base consular revela que del $23 \%$ que no vino de Lima, un 9\% residía en el Departamento de la Libertad (99\%, en Trujillo); 3,2\% en Arequipa ( $90 \%$, Arequipa ciudad); $1,7 \%$ en Lambayeque ( $96 \%$, Chiclayo) y $1,7 \%$ en Ancash ( $81 \%$ en Chimbote); entre otras procedencias.
} 
La sociedad peruana es muy clasista. Una conocida, que [en Madrid] hablaba que si sus hijos iban a tal guardería, que tal [dándose importancia], pues su madre [la de Helio] fue una vez a Lima y esta conocida le pidió llevar una cosa pero no quería que supiera dónde vivía. Al final resultó que era en las afueras del Callao, en una zona [dice Helio] en la que tú no puedes entrar de noche.

Entre sus amigos íntimos está Carlos, un miembro de la hermandad, limeño de Surquillo de clase media baja e hijo de emigrantes, que trabajaba en Lima como empleado público. Lo conocieron al poco de llegar a Madrid y también se dedica al cuidado de ancianos. Él es más explícito con respecto a las diferencias con los campesinos serranos, señalando la competencia lingüística como otro elemento de diferenciación (Twanama 1992: 222):

Es que están más lejos de Lima. Son considerados [...] campesinos, pero de las alturas. Sabes que hay pueblos donde no hablan español. Para nosotros que somos de Lima, cuando vamos a esos sitios, pues [...] nos ven como intrusos [...]. Y también en Lima hay la mentalidad de que ellos son tontos y hay que aprovecharse de ellos. Pero también es un problema la amistad allí. Tienes que aceptarle todo [...], la bebida que te dan; y si te das una borrachera eres buenísimo y, si comes y estás devolviendo [...], se sienten felices, porque te han brindado todo hasta que revientes.

Carlos se refiere a los de barriada en estos términos, mostrando una opinión generalizada, propia de su escaso conocimiento de esa realidad y ubicándose a sí mismo en un nivel medio:

Yo he visto casos en los "pueblos jóvenes", marginales... Ese tipo de gente proliferó y allá he visto niños comer hasta comida de animales. A los pollos se les da unas harinas y he visto a los niños comer eso [...]. Hay otro nivel medio, donde sí tienes alcance a comer, pero no a comprar carne todos los días.

Dentro de la hermandad, son los "profesionales" y limeños criollos de barrio céntrico. Saben más sobre las cuestiones asociativas que el resto por su formación, se consideran los más informados y cualificados para ello, y suelen ocupar los puestos directivos. Para ellos, la asociación es un espacio de reconocimiento, además de una oportunidad para la amistad y el intercambio de información, necesaria en su vida de emigrantes. Viven su devoción al Señor de los Milagros como una proyección de su fe católica en Cristo, su Cristo peruano, una imagen que forma parte de la historia de Perú, como una cuestión cultural, desde una visión más racional y "moderna".

Viene de generación en generación y ya tiene que ver con la historia del Perú [...]. El hecho de traerla no tiene nada que ver con lo divino. Todos necesitamos 
un punto de apoyo para proyectarse, la fe también. Entonces ese Señor de los Milagros que se pintó y al que se le atribuyen los milagros solamente es una cultura, se le atribuyen milagros, dicen que eran, dicen que no eran, quizá entre tú y yo, que somos modernos, digamos que no, nos quede la duda; el caso es que es así [...]. Aquí te sientes vacío, porque ves Cristos pero no el tuyo [...]; eso hace que nos reunamos y traigamos una réplica de allí para podernos reflejar y ver lo que queremos ver: al Cristo de los Milagros con sus adornos como está allá.

Fuera de la hermandad, la afinidad local se muestra relevante frente a otros criterios de sociabilidad si los amigos del barrio también han emigrado. Algunos de los "patas" de Helio, de la "cuadra", están en Madrid. Con ellos no sólo comparte barrio, formación académica y aspiraciones, sino también una jerga, un pasado común, una confianza especial y "un respeto para.. [el que es] familiar o conocido" (Portocarrero y Komadina 2001: 82). Los invita a las fiestas familiares en casa, se ayudan en la búsqueda de trabajo, se intercambian noticias de la gente del barrio e incluso con algunos, residentes en Lima, se comunican por Internet. Uno de ellos es cuñado suyo y vive cerca de su casa. Helio se acuerda de Breña, como Elena, de Piura; las pocas veces que han retornado a Perú han vuelto a su lugar de origen y han buscado el reencuentro con sus amigos de la infancia y adolescencia. Pero no viajan a menudo, por los elevados gastos que supone no sólo el pasaje sino también la obligada necesidad de mantener las apariencias como emigrantes exitosos, algo que no pueden permitirse con tres hijos a su cargo.

Elena no sale en Madrid con los "patas" de Helio y tampoco le gusta mucho que su esposo vaya, porque la mayoría son solteros. A pesar de ello, y con excusas, él sí los ve en restaurantes o en casa de alguno, donde recuerdan su particular jerga limeña y escuchan su música de los ochenta, rock y pop americano, peruano y argentino. Con los amigos de la hermandad, en cambio, Helio y Elena sí salen juntos. Cuando pueden dejar a los niños con algún familiar, suelen ir a comer a algún restaurante o a discotecas. Afirman preferir salir en pareja, una diferencia que marcan con los españoles, a los que identifican como europeos. En ese sentido se reconocen diferentes y mantienen la costumbre que seguían en Lima de salir juntos una vez casados:

[Elena dice:] salimos juntos. Eso [de salir separados] lo viví en Dinamarca, me vine por allá para poder venir aquí. Era hermano de su cuñado, casado con danesa. Tenían dos hijos. [Decían:] "pues hoy me toca salir a mí". Se lo contaba [a Helio] y me decía "estás en Europa". [Helio dice:] en un matrimonio cambia; allá en Perú la dejaba, de novios, en su casa y me encontraba con mis amigos y su hermano. "Que hay una fiesta"[...] y se iba ella. Pero ya de casados cambia.

Su sociabilidad se ve marcada no sólo por su posición social en Lima, su identificación étnica y su adscripción local, sino también por su doble 
condición de matrimonio con niños. En la hermandad, sus amigos son parejas también y no acuden a las reuniones de los solteros. A las asambleas y otras actividades más formales suele ir Helio, mientras que a la procesión y a las fiestas de colecta acude toda la familia. Las relaciones sociales se establecen por género y por estado civil. Dentro y fuera de la hermandad lo común es que solteros y casados no se mezclen y que cuando se junten los casados, se relacionen hombres y mujeres por separado, formen grupo aparte para "conversar sus cosas":

Ahí en el grupo se encontraban, se pasaban la voz de lo que sucedía. Ya sabes, un grupo de amigos, todo lo que se puede pasar... De trabajo... que quieres comprar ropa y la amiga te dice que en tal sitio venden más barato [...] o un coche y te dicen: "pues tal amigo quiere vender". O sea, la comunicación de esas cosas que tú puedes estar necesitando y en ese momento alguien tiene un dato y te lo da; bueno, como en cualquier grupo de amigos.

Con mayor frecuencia se encuentran con sus familiares, con los que pasan la mayor parte de su tiempo libre, además de la comunicación constante por teléfono y con los que han creado una red de apoyo. En Madrid, Elena tiene una hermana y Helio cinco con estudios universitarios, casadas y con niños, además de su madre viuda que vive con ellos. Cualquier excusa es buena para reunirse. Son tantos familiares que casi todos los meses se juntan en casa de alguno para celebrar los cumpleaños, con su comida peruana y su música favorita: pop, bolero, huaino, vals criollo. Al gusto de todos, según la edad.

Una familia tan extensa se convierte en un grupo social de referencia que ellos refuerzan con sus contactos. Tienen en común el que sus padres habían alcanzado cierto nivel socioeconómico que perdieron con la crisis económica. El capital familiar les permitió estudiar una carrera con la que quieren prosperar en la vida. Si Lima les negaba esa posibilidad, quisieron creer que Madrid se la brindaba, lo que les permitiría continuar creyendo en el mito del progreso, en la movilidad social a través de la formación (Degregori 1986).

Se tiene la idea [dice Elena] de que si vienes de Europa, vienes con dinero; eso a raíz de que antes se tergiversaba la cosa: "sí, me va muy bien, gano tanto. ¡Uy!, sí, vente". No era verdad y por eso mucha gente se ha venido engañada y claro... Porque la sociedad peruana es muy clasista y siempre necesitas mantenerte allí, sobre todo cuando has estudiado o por lo menos has tenido una época que tus padres te han podido dar. Has tenido un nivelillo alli, pues tratas de mantenerlo, de superarlo.

A pesar de los años que llevan en España, no tienen amigos nacidos aquí. Sus relaciones con ellos son a través del trabajo y por medio de 
sus hijos, con los padres de sus compañeros de colegio. En el terreno laboral, consideran que su imposibilidad de encontrar empleo como laboratoristas en España se debe a la preferencia de los empleadores por los españoles. Sin mencionar el término discriminación, comentan: "Siempre hay una inclinación al español, la plaza de trabajo la reservan más para el español... En laboratorio tú vas a ver que no hay extranjeros; todos [son] españoles".

En su entorno laboral y con el paso del tiempo, han entablado amistad con una española. Se trata de la hija soltera de una anciana a la que Elena cuidó durante varios años hasta su fallecimiento: una señora ya mayor con la que mantienen una relación de confianza, agradecimiento y de escasos encuentros. Ella les ha hecho varios favores; el más importante fue un préstamo de dinero en un momento de necesidad. Ella, por su parte, confía en que la cuiden cuando lo necesite. Helio y Elena la han invitado a ceremonias familiares, como el bautizo o la comunión de alguno de sus niños.

A través de la relación de sus hijos con sus compañeros del colegio, conversan ocasionalmente con padres españoles. Se encuentran con ellos cuando recogen a sus hijos del colegio o de casa de sus amigos, pero no pasan de conocidos. Como padres, no se identifican con los españoles. Helio y Elena dedican una atención constante a sus hijos: les ayudan a hacer los deberes escolares, fomentan las relaciones con sus primos y los educan en lo que consideran las costumbres peruanas; por ejemplo, organizan los cumpleaños de los niños en casa.

Es una costumbre que tenemos, la de hacer el cumpleaños en casa [...]. Con piñata, globos, serpentina, bocaditos, gelatinas. Este año le hicimos el cumple a mi hijo, le hicimos la tarta [...]. En ese sentido, [...] somos muy tradicionalistas, o sea, porque al MacDonald pues te evitas preparativos [...]. Por integrarte, por llevar la costumbre aquí, pero luego las fiestas [en casa] terminan bonitas... y en MacDonald están los niños, no están los padres, en una piscina de bolas y nada, no me gusta mucho. A casa mejor, se lo pasan mejor.

Se integran en la sociedad española de una manera crítica (Rouse 1992). $\mathrm{Ni}$ se aferran a su peruanidad de por vida ni se sienten españoles. Mientras mantienen la costumbre de comer los domingos en un restaurante peruano, han incorporado el acento español y la jerga madrileña o el salir a terrazas y bares de Madrid con su familia.

\section{CONCLUSIONES}

Luis, Helio y Elena son limeños devotos del Señor de los Milagros, que emigraron en los noventa como la gran mayoría de los peruanos en 
España. Son miembros de las hermandades que representan, respectivamente, al sector popular de origen andino que emergió en la Lima de las últimas décadas y a la clase media baja empobrecida por la crisis económica y aterrorizada por el terrorismo desde fines de los ochenta. Ambos tenían escasas oportunidades en su país y las buscan en el nuevo destino. No se trata ni de los limeños criollos "pitucos" ni de los arequipeños o trujillanos, ni los de Huancayo o Puno que emigraron a la capital años antes de cruzar el Atlántico; aunque en menor proporción, éstos también forman parte de las hermandades y son una prueba más de la diversidad interna que existe entre los originarios de Perú en Madrid.

Las hermandades se componen de peruanos que han nacido, o vivido gran parte de su vida, en Lima: criollos y gente de provincias o sus descendientes, acriollados y mestizos, que han contribuido a la diversidad cultural de la sociedad limeña contemporánea. Son personas de diferente origen social, status profesional y de barrios de residencia tan distintos como San Juan de Lurigancho, Breña, Miraflores; individuos que vislumbraron, y después vieron mermarse, sus posibilidades de movilidad social, al tiempo que se multiplicaban las estratificaciones sociales, y cada uno desde su posición, fue incluyendo nuevos códigos al juego nacional de "cholear".

Helio, Elena y Luis comparten su experiencia migratoria en Madrid; para ellos una cosa quedó clara al principio: no nacieron en España, son emigrantes de otro lugar. Aquí, el mercado secundario les ofrece empleos no cualificados en los servicios y la construcción, ni estables ni bien pagados. La administración española les hace ir y venir constantemente a las oficinas públicas a tramitar documentos y experimentan la inseguridad de su situación, la ilegalidad que conlleva la caducidad de los permisos iniciales y las actitudes y gestos discriminatorios. Escuchan palabras y ven calles que no conocen y comienzan a añorar los rincones de su ciudad y los rostros de familiares y amigos. A nivel local, en lo cotidiano, la categoría nacional se vuelve relevante desde su conciencia de no ser ni españoles ni europeos ante las dificultades que encuentran por no serlo y al no reconocer el nuevo espacio como su lugar. Luis sólo ha probado la gastronomía española en tres ocasiones durante los dos años que lleva en Madrid, y se prepara su comida peruana o la degusta en los bares y restaurantes de peruanos.

En Madrid, la sociabilidad de Luis, Helio y Elena se ha visto desarrollada a través del encuentro en nuevos espacios en Madrid (las calles, los parques, las parroquias) y a través de la reconstrucción colectiva de nuevos lugares sociales en esos espacios (los bares y restaurantes peruanos, las hermandades, sus casas). En la recomposición de sus relaciones socia- 
les, ha entrado en juego una combinación de elementos, tales como su lugar de procedencia (origen costeño o serrano, urbano o rural y el distrito de residencia), su status en Lima y en Madrid (marcado por su origen social y local, su ocupación y su nivel de instrucción) y el género.

La sociabilidad de Helio, Elena y Luis con sus connacionales se genera, en parte, en torno a su devoción al Señor de los Milagros: comparten, tanto su deseo de mantener las costumbres gastronómicas, musicales y los recuerdos, como la creencia en el mito del progreso a través de su esfuerzo personal y de la ayuda de Dios o la del Cristo de los Milagros, que para ellos no sólo es lo mismo sino que además es su Cristo peruano. A partir de su invocación común al Cristo de los Milagros en los momentos de necesidad, Helio y Elena, perciben su devoción de un modo más racional y moderno, como parte de su cultura entre otras culturas. En cambio, Luis lo vive de manera más emotiva y esencialista, explicando sus éxitos y fracasos por la intervención divina. Dos percepciones diferentes, producto de contextos locales distintos en Lima y en Madrid.

Helio y Elena residían en barrios céntricos de Lima, populares y mixtos, y presumen de su origen no andino, su criollismo, su nivel académico y del status que habían alcanzado allí. En la hermandad de María Inmaculada han formado su grupo de amigos con gente "educada", profesionales de barrios populares o mixtos, acriollados, como ellos, y han alcanzado cierto grado de reconocimiento; otros hermanos proceden de barriadas limeñas o de provincias, son de origen andino o carecen de su formación universitaria.

En cambio, Luis es de barriada; esgrime su astucia, su laboriosidad y su enorme confianza en Dios, reconociendo su origen popular, como participante de una cultura mestiza urbana de rasgos más andinos. En la hermandad de San Romualdo, hay limeños criollos, de mayor status que él en Lima, con los que no se relaciona. Entre los hermanos que también son de barriada como él, se le reconoce su nivel de instrucción, pero se le discrimina desde el juego de olvidar y disimular los orígenes sociales, un juego bastante común entre aquellos procedentes de lugares humildes.

Los amigos de Helio y Elena son limeños de barrios céntricos, con estudios, que se emplean en ocupaciones parecidas a las suyas y están casados. Luis va con los de su barriada, que trabajan en la construcción como él y están en la hermandad o frecuentan los bares de peruanos. Mientras que para Luis "tomar" es una forma de compartir, estimar y reconocer a los iguales de su género y, para los hermanos de su cuadrilla, no beber significaría una de falta de hombría, para Helio y Elena beber es un signo de atraso e ignorancia, propio de provincianos campesinos. 
Luis caracteriza al "buen peruano" como el que mantiene las costumbres, devuelve los favores (reciprocidad), es trabajador (laboriosidad) y confía en Dios (confianza mágica); cualidades atribuidas a los sectores populares urbanos - que han experimentado e impulsado la Lima mestiza desde la combinación de elementos andinos y criollos-. Él se considera peruano, de barriada y profesional; en ningún caso se reconoce limeño. Para él la devoción al Señor de los Milagros es peruana. Elena y Helio, en cambio se sienten peruanos desde su sentirse limeños participantes de la cultura criolla; de la misma manera, entienden que el Señor de los Milagros es peruano porque es limeño.

El proceso migratorio acentúa la peruanidad de los tres en Madrid. En este sentido, la creación y participación en las hermandades del Señor de los Milagros es, tanto un producto, como el instrumento que promueve y facilita el sentido de pertenencia nacional. Al mismo tiempo, esa peruanidad se percibe de diferente modo en la vida diaria de estos devotos, según sus condiciones materiales, sociales y culturales en Lima y en Madrid. Así mismo, la procedencia regional y barrial, la etnia, el status social, la calificación académica y el género, son marcas cotidianas y sutiles de identificación y diferenciación entre ellos. Son más amigos los que vivieron en el mismo barrio o estudiaron en el mismo colegio o universidad; sus iguales son su referente, de ellos esperan ayuda y reconocimiento.

Estos criterios articulan las estratificaciones internas entre los devotos del Señor de los Milagros. Las fronteras internas entre los inmigrantes peruanos prevalecen pero al mismo tiempo facilitan su integración parcial, entre ellos. En ocasiones, el contexto migratorio puede transformar relativamente la posición de algunos en este juego clasificatorio; dicho de otro modo, unos pueden tener más suerte que otros y transgredir hasta cierto punto las fronteras sociales. Pero si los de barriada encuentran posibilidades de movilidad social y pueden alcanzar una mejor posición en este contexto migratorio de discontinuidad, cuando traten con otros limeños persistirá la estratificación social que vivían en Lima. Elementos como el origen social, el barrio de procedencia, el nivel educativo o su clasificación étnica, contarán a la hora de "cholear" o de ser "choleados".

En cualquier caso, el manejar estos códigos que generan estratificación desde lo local, el participar en estos múltiples juegos clasificatorios, es algo bien "peruano" para estos inmigrantes, una de sus marcas de identidad nacional. El localismo y la segmentación social pudiera ser vivido como una marca de identidad nacional. En esta articulación compleja de sutiles marcas diferenciadoras del "nosotros" y el "ellos" hay continuidades latentes respecto de sus condiciones de origen que estructuran el lugar 
social que crean en Madrid, que los inmigrantes peruanos ponen en juego en el escenario de discontinuidad que genera el proceso migratorio.

\section{BIBLIOGRAFÍA CITADA}

Altamirano, Té́filo. 1992. Éxodo: Peruanos en el exterior. Lima: Pontificia Universidad Católica del Perú.

Álvarez, Augusto. 1995. "Del Estado empresario al Estado regulador" en Julio Cotler (ed.), Perú 1964-1994: economia, sociedad y política: 69-91. Lima: IEP.

ApPADURAI, ARJun. 1996. Modernity at Large: Cultural Dimensions of Globalization, Minneapolis: University of Minnesota Press.

BOURDIEU, Pierre. 1998. Practical Reason. California : Standford University Press.

CELESTINO, Olinda y AlBert MEyers. 1981. Las Cofradias en el Perú: región central. Frankfurt: Vervuert.

Colectivo IOÉ. 1990. Trabajadoras Extranjeras en Servicio Doméstico en Madrid. Ginebra: Organización Internacional del Trabajo.

- 1998. Inmigración y Trabajo: Trabajadores Inmigrantes en el sector de la construcción. Madrid: Ministerio de Trabajo y Asuntos Sociales.

Cosamalón, ANa lucía. 1993. "Notas sobre el uso de la palabra cholo", en Gonzalo Portocarrero (ed.), Los nuevos limeños. Sueños, fervores y caminos en el mundo popular: 279-284. Lima: SUR/TAFOS.

Degregori, CARlos IVÁn. 1986. "Del mito de Inkarrí al mito del progreso: poblaciones andinas, cultura e identidad nacional". Socialismo y Participación 36: 49-55.

Degregori, Carlos Iván, CeCILIA Blondet y Nicolás LynCH. 1986. Conquistadores de un Nuevo Mundo: De invasores a ciudadanos en San Martín de Porres. Lima: Instituto de Estudios Peruanos.

-. 1995. "El estudio del otro: cambios en los análisis sobre etnicidad en el Perú", en Julio Cotler (ed.), Perí 1964-1994: economía, sociedad y politica: 303-332. Lima: Instituto de Estudios Peruanos.

DRIANT, JEAN-ClAUDE. 1991. Las barriadas de Lima. Historia e interpretación. Lima: Instituto Francés de Estudios Andinos y Centro de Estudios y Promoción del Desarrollo.

DuANY, JORGE. 2000. "Nation on the Move: the Construction of Cultural Identities in Puerto Rico and the Diaspora". American Ethnologist 27 (1): 5-30.

FigueroA, AdOlfo. 1995. "La cuestión distributiva en el Perú", en Julio Cotler (ed.), Perú 1964-1994: economía, sociedad y política: 17-39. Lima: IEP.

FRANCO, CARLOS. 1991. Imágenes de la sociedad peruana: la "otra" modernidad. Lima: Centro de Estudios para el Desarrollo y la Participación.

Friedman, Jonathan. 1997. "Global Crises, the Struggle for Cultural Identity and Intellectual Porkbarrelling: Cosmopolitans versus Locals, Ethnics and Nationals in an Era of De-hegemonisation", en Pnina Werbner y Tariq Modood (eds), Debating Cultural Hybridity: 70-89. Londres: Zed Books.

FuENZAlidA, FERnANDO. 1970. "Poder, Raza y Etnia en el Perú Contemporáneo", en Instituto de Estudios Peruanos (ed.), El indio y el poder en el Perú: 15-87. Lima: Moncloa-Campodonico Editores Asociados.

Golte, JuRGEN. 1995. "Nuevos actores y culturas antiguas" en Julio Cotler (ed.), Perú 1964-1994: economia, sociedad y política: 135-148. Lima: IEP. 
GOLTE, JURGEN y NORA ADAMS. 1987. Los caballos de Troya de los invasores: Estrategias campesinas en la gran conquista de Lima. Lima: IEP.

GONZÁles DE OlaRTE, EFrAín. 1995. "Transformación sin desarrollo: Perú 1964-1994", en Julio Cotler (ed.), Perí 1964-1994: economía, sociedad y política: 41-68. Lima: Instituto de Estudios Peruanos.

GuPTA, AKhil y James Ferguson. 1997. "Beyond Culture: Space, Identity and the Politics of Difference", en Akhil Gupta y James Ferguson (eds.), Culture, Power, Place: Explorations in Critical Anthropology: 33-51. Durham: Duke University Press.

INEI (Instituto Nacional de Estadística e Informática). 1993a. "Distrito de San Juan de Lurigancho. Cuadro 46: Población ocupada de 15 años y más, por categoría de ocupación, según área urbana y rural, sexo y nivel de educación alcanzado", en IX Censo Nacional de Población y IV de Vivienda 1993. Lima. http://www.inei.gov.pe

—. 1993b. "Distrito de Breña. Cuadro 46: Población ocupada de 15 años y más, por categoría de ocupación, según área urbana y rural, sexo y nivel de educación alcanzado", en IX Censo Nacional de Población y IV de Vivienda 1993. Lima. http:/ /www.inei.gov.pe

—. 1993c. "Distrito de San Juan de Lurigancho. Cuadro 9: Población de 5 años y más, por grupos decenales de edad, según área urbana y rural, sexo e idioma o dialecto materno aprendido en su niñez", en IX Censo Nacional de Población y IV de Vivienda 1993. Lima,. http://www.inei.gov.pe

MALKKI, LIISA. 1997. "National Geographic: The Rooting of People and the Territorialization of National Identity among Scholars and Refugees", en Akhil Gupta y James Ferguson (eds.), Culture, Power, Place: Explorations in Critical Anthropology: 5274. Durham: Duke University Press.

MATOS, JosÉ. 1988. Desborde popular y crisis del Estado. El nuevo rostro del Perú en la década de 1980. Lima: CONCYTEC.

MAYER, ENRIQUe. 1970. "Mestizo e Indio: el contexto social de las relaciones interétnicas", en Instituto de Estudios Peruanos (ed.), El indio y el poder en el Perú: 88-152. Lima: Moncloa-Campodonico Editores Asociados.

MERINO, M. ASUNCIÓN. 1999. La inmigración peruana en Madrid: ámbitos y dinámicas asociativas. Tesis doctoral. Madrid: Facultad de Sociología. Universidad Complutense (inédita)

- 2002a. "Políticas de pertenencia y relaciones coloniales: la inmigración peruana en España". Anuario de Estudios Americanos LIX-2: 589-608.

- 2002b. Historia de los inmigrantes peruanos en España. Dinámicas de exclusión e inclusión en una Europa globalizada. Madrid: CSIC.

Ministerio de Trabajo y Asuntos Sociales. 1999. Anuario de Migraciones 1998. Madrid: Ministerio de Trabajo y Asuntos Sociales.

- Anuario de Migraciones 2002. Madrid: Ministerio de Trabajo y Asuntos Sociales.

MinisTerio DE ENERGía y MinAS. 2004. "Aspectos socioeconómicos", en Construcción y Operación de las Redes Secundarias de las otras Redes de Distribución. Proyecto Camisea, Estudios de Impacto Ambiental. http://www.minem.gob.pe/ camisea/estudios/ redes/aspectos.pdf

PONCE, ANA. 1995. "Perú: perfil sociodemográfico 1972-93", en Gonzalo Portocarrero y Marcel Valcárcel (eds), El Perú frente al Siglo XXI: 127-156. Lima: Pontificia Universidad Católica del Perú.

PAERREGARD, KARSTEN. 2004. Latino Nationalism: Negotiating National and Multicultural Identities among Peruvians in the United States. (inédito). 
Portes, Alejandro, y Rubén G. Rumbaut. 1990. Immigrant America. Berkeley: University of California Press.

Portocarrero, Gonzalo. 1993a. "Introducción. Ajuste de cuentas: cuatro años de TEMPO", en Gonzalo Portocarrero (ed.), Los Nuevos Limeños. Sueños, fervores $y$ caminos en el mundo popular. 9-37. Lima: Sur-Tafos.

-. 1993b. "Un mediodía con Sarita" en Gonzalo Portocarrero (ed.), Los Nuevos Limeños. Sueños, fervores y caminos en el mundo popular. 177-183. Lima: Sur-Tafos.

Portocarrero, Gonzalo y Jorge Komadina. 2001. Modelos de identidad y sentidos de pertenencia en Perú y Bolivia. Lima: Instituto de Estudios Peruanos.

Portocarrero, Gonzalo; ISIDRO VAlENTín y SORAYA IrIGOYEN. 1991. Sacaojos. Crisis social $y$ fantasmas coloniales. Lima: Tarea.

PROTZEL, JAVIER. 1999. "National and International Flows of Migration: Different Configurations of Self and Memory among Peruvians". HUGG Berlin Conference: Globalization and Cultural Security: Migration and Negotiations of Identity, October $15-17^{\text {th }}$.

- 2001. "Continuidades, hibridaciones y rupturas. Un ensayo sobre la interculturalidad en el Perú". América Latina Hoy 28: 149-169.

Quijano, Aníbal. 1980. Dominación y cultura. Lo cholo y el conflicto cultural en el Perí. Lima: Mosca Azul Editores.

ReAl ACADEmia EsPañola. 2003. Diccionario de la lengua española. Madrid: Espasa Calpe. Riofrí, GuSTAVO. 2003. "The case of Lima, Peru", en Development Planning Unit (DPU), University College London (UCL), Understanding Slums: Case Studies for the Global Report on Human Settlements. http://www.ucl.ac.uk/dpu-projects/Global_ Report/ cities/lima.htm

ROMERO, ANTONIO. 2003. La economía urbana de Lima Metropolitana: los procesos y retos de desarrollo. http://www.urbared.ungs.edu.ar/recursos_bibliografia_trabajos _ consul_lect.htm

ROUSE, ROGER. 1992. "Making Sense of Settlement: Class Transformation, Cultural Struggle, and Transnationalism in the United States", en Nina Glick-Shiller et al. (eds.), Towards a transnational perspective on migration: race, class, etbnicity, and nationalism reconsidered: 25-52. Nueva York: The New York Academy of Sciences.

SASSEN, SASKIA. 2000. Cities in a World Economy. Londres: Pine Forge Press.

STEIN, William W. 2003. "The Street Signs of Downtown Lima. Memory and Identity in Peru". Ciberayllu 25. http://www.andes.missouri.edu/andes/especiales/ WSStreetSigns/ WS_StreetSigns_1.html

STEPICK, AlEX y Gulllermo Grenier. 1994. "The View from the Back of the House: Restaurants and Hotels in Miami”, en Louise Lamphere, Alex Stepick y Guillermo Grenier (eds), Newcomers in the workplace. Immigrants and the restructuring of the US Economy: 181-196. Filadelfia: Temple University Press.

Thomas, Jim. 1999. "El mercado laboral y el empleo", en John Crabtree y Jim Thomas (eds), El Perú De Fujimori: 1990-1998: 231-262. Lima: Universidad Del Pacífico e Instituto de Estudios Peruanos.

TwanAma, WALter. 1992. “Cholear en Lima”. Márgenes 9: 206-242.

VERDERA, FRANCISCO. 1997. "Mercado de trabajo, reforma laboral y creación de empleo: Perú, 1990-95". Documento de trabajo 87. Lima: IEP. 